University of South Florida

DIGITAL COMMONS

Digital Commons @ University of

@ UNIVERSITY OF SOUTH FLORIDA

South Florida

QMaSC: A Handbook for Directors of

Quantitative and Mathematics Support Centers

USF Libraries

$1-1-2016$

\title{
16. Internal Evaluation and Reporting
}

Tiana Bosley

Wayne State University

Follow this and additional works at: https://digitalcommons.usf.edu/qmasc_handbook

\section{Recommended Citation}

Tiana Bosley (2016), "Internal Evaluation and Reporting", http://dx.doi.org/10.5038/9780977674435.ch16 in G. Coulombe, M. O'Neill, M. Schuckers (Eds.) A Handbook for Directors of Quantitative and Mathematical Support Centers, Neck Quill Press, http://scholarcommons.usf.edu/qmasc_handbook.

This Center Assessment is brought to you for free and open access by the USF Libraries at Digital Commons @ University of South Florida. It has been accepted for inclusion in QMaSC: A Handbook for Directors of Quantitative and Mathematics Support Centers by an authorized administrator of Digital Commons @ University of South Florida. For more information, please contact digitalcommons@usf.edu. 


\title{
Internal Evaluation And Reporting
}

\author{
(c) Tiana Bosley,
}

Wayne State University

吅

\section{Introduction}

This chapter discusses some elements of internal evaluation of a Quantitative and Mathematics Support Center (QMaSC) from the prospective of a center director. To understand how to conduct an internal evaluation, it is good to have a clear understanding of what internal evaluation involves. After explaining this information, the chapter discusses a specific method of evaluation that can be applied to a mathematics or quantitative center that is in the early stages of acquiring data. This means that the internal evaluation refers only to the operation of the center; comparisons with other centers are addressed in the chapter involving external evaluation.

J. L. Fitzpatrick defines evaluation as "the identification, clarification, and application of defensible criteria to determine an evaluation object's value, its merit or worth, in regard to those criteria" [1]. Evaluation consists of several levels requiring preparation that may include focusing the evaluation on decision-making criteria, specifying the type of data for collection, organizing the format and design of the information, choosing appropriate methods of analyzing the information, specifying the type of information, identifying recipients of the reports, and administering the evaluation. It can be performed by internal, and/or external evaluators.

"Internal evaluation traditionally has been viewed - and largely practiced - as a staff function informing operations, management, and/or strategic planning" [2]. Thus, a QMaSC's evaluation can be performed by the director or coordinator of the center or by staff appointed by a manager

Suggested Citation: Tiana Bosley (2016), "Internal Evaluation And Reporting", http://dx.doi.org/10.5038/ 9780977674435.ch16 in G. Coulombe, M. O'Neill, M. Schuckers (Eds.) A Handbook for Directors of Quantitative and Mathematical Support Centers, Neck Quill Press, http://scholarcommons.usf.edu/qmasc_handbook.

This material is based upon work supported, in part, by the National Science Foundation under Grant DUE1255945. Any opinions, findings, and conclusions or recommendations expressed in this material are those of the author(s) and do not necessarily reflect the views of the National Science Foundation 
to operate as an evaluation committee or group. Center directors or coordinators can determine their method of internal evaluation by considering the size of their center and the budget allowed for the evaluation.

There are both benefits and disadvantages to internal evaluation. "Internal evaluators are likely to know more about the program, its history, its staff, its clients, and its struggles than any outsider" [1]. This type of evaluation can be conducted by the center director and staff. It can be a budget-friendly option. However, an internal evaluator may be too close to the program and subject to bias, so an external evaluation may be necessary.

\section{Basic Evaluation Roles}

Evaluation can take on two roles, formative or summative. An evaluation is categorized as formative if the results of the evaluation are to be used to improve the program. "Formative data collected during the early stages of a program can help identify problems in the program model or theory or in the early delivery of the program that can be modified or corrected" [1]. This data can contribute to the creation of new or additional programs. The summative evaluation approach is often used to assist in making decisions about the continuation or adoption of a program. Initially, in a mathematics or quantitative center, a formative evaluation may be the most suitable method. Summative evaluation can be used in the future if the center's coordinators or directors plan to expand the program beyond their institution.

Before a formative evaluation begins, the role of the evaluator must be negotiated and the goals of the program should be clearly defined. For example, the main goal of a research institute's QMaSC may be to help WSU students develop mathematical skills necessary to be successful learners through the creation of a safe and friendly learning environment. It is the job of the internal evaluator to determine if these goals are being met. It can be useful to implement a decision-oriented and descriptive formative evaluation plan.

Prior to his position as an emeritus professor and director at the Western Michigan University Evaluation Center, Daniel Stufflebeam created the CIPP (Context, Input, Process, and Product) Evaluation Model that can be applied to help in decision-making and quality assurance. The Context of the program guides planning, Input relates to structuring decisions, Process is for implementing decisions, and Product is for recycling decisions. J. L. Fitspatrick calls Stufflebeam "a leader in developing an approach oriented to decisions" [1]. The CIPP Evaluation Model Checklist [3] can be a useful guide for conducting a math center's evaluation. An example of the steps in this method as applied to a QMaSC are presented in Table 1.

The descriptive design of the evaluation should include elements of a cross-sectional design to survey and observe the program as it relates to students and tutors utilizing the center. Eventually, this form of evaluation will provide outcomes that will help management to modify this program 
and continuously re-evaluate any adjustments in future stages. Thus, a descriptive design will assist with the four stages of evaluation implementation in the CIPP Evaluation Model.

Table 1: Example of the CIPP Evaluation Model for a QMaSC

\begin{tabular}{|c|c|c|c|}
\hline $\begin{array}{l}\text { Context } \\
\text { Evaluation }\end{array}$ & Input Evaluation & $\begin{array}{l}\text { Process } \\
\text { Evaluation }\end{array}$ & $\begin{array}{l}\text { Program } \\
\text { Evaluation }\end{array}$ \\
\hline $\begin{array}{l}\text { The QMaSC will } \\
\text { use these findings } \\
\text { for review and } \\
\text { revision of their } \\
\text { goals to properly } \\
\text { target assessed } \\
\text { needs. }\end{array}$ & $\begin{array}{l}\text { The QMaSC will } \\
\text { maintain records } \\
\text { of program } \\
\text { events, problems, } \\
\text { costs, and } \\
\text { allocations. }\end{array}$ & $\begin{array}{l}\text { The QMaSC will } \\
\text { use these findings } \\
\text { to coordinate and } \\
\text { strengthen staff } \\
\text { activities. }\end{array}$ & $\begin{array}{l}\text { The QMaSC will } \\
\text { use these findings } \\
\text { to judge the } \\
\text { extent to which } \\
\text { its tutoring } \\
\text { program is } \\
\text { serving or did } \\
\text { serve its tutees. }\end{array}$ \\
\hline $\begin{array}{l}\text { The QMaSC will } \\
\text { use this step } \\
\text { throughout the } \\
\text { entirety of its } \\
\text { tutoring program } \\
\text { to assist in } \\
\text { assessment of its } \\
\text { effectiveness and } \\
\text { significance. }\end{array}$ & $\begin{array}{l}\text { The QMaSC will } \\
\text { maintain an } \\
\text { up-to-date profile } \\
\text { of the tutoring } \\
\text { program offered } \\
\text { by the QMaSC. }\end{array}$ & $\begin{array}{l}\text { The QMaSC will } \\
\text { use these findings } \\
\text { to report on the } \\
\text { center's progress } \\
\text { to the financial } \\
\text { sponsors, the } \\
\text { college or } \\
\text { university. }\end{array}$ & $\begin{array}{l}\text { It will also use } \\
\text { these findings to } \\
\text { judge the extent } \\
\text { to which its } \\
\text { programs have } \\
\text { addressed or are } \\
\text { addressing } \\
\text { important needs } \\
\text { of the university } \\
\text { community. }\end{array}$ \\
\hline
\end{tabular}

There are some limitations to this formative evaluation approach. This evaluation can only provide information for evaluating a specific center based on the goals of that center. It will be necessary to repeat the evaluation over several terms to collect enough data for comparisons with other tutorial programs. Moreover, the purpose is to assess quality assurance, and the program coordinator or director will have more explicit decision-making responsibilities than other stakeholders (tutees and staff) in the program. This could lend itself to bias in the collection and interpretation of data unless an external evaluator is also utilized or different methods of data collection are used to assess the same item to discover if the results of the analysis are comparable.

\section{Components of the Evaluation}

Stufflebeam further explains, "Sound evaluations are grounded in clear and appropriate values (principles, attributes, or qualities held to be intrinsically good, desirable, important, and of general worth) and criteria (standards on which to base judgments)" [4]. An internal evaluation should 
be guided by questions that address the overall quality of the center. These questions can focus on environmental factors, tutor subject and skill proficiency, tutoring benefits and resource availability. The center should be the main source for data collection because it can be used to observe the interactions of the tutors and students and to supply students with the survey instruments.

Several methods can be used to collect data. They can include documents, records, observations, surveys, interviews, focus groups and/or tests. Some of this data can be collected directly from individuals. For example, a center director may require tutors to submit their transcripts to validate their mathematical background. Data can also be collected via an assessment test given to tutors each academic year to assess their current mathematical skills. Equally important, the program director/coordinator can use face-to-face interviews to observe the tutor's overall method of tutoring through questions and role-play situations. An additional data collection source is the information collected by the center on a regular basis. This can be a useful and inexpensive source of information. Attendance records are a good example of this type of data. They are collected on a daily basis and can provide the frequency of the visits of each tutee and listings of courses that require the most assistance for students. This is important when a center coordinator or director decides to make improvements in the services of the center such as having tutors review subject areas that cause the most confusion or operating the center during hours that are most needed by its client population.

The internal evaluator must decide on the types of instruments (surveys, tests, etc.) to be used to carry out the evaluation. Most often, the program coordinator or director creates the necessary instrument for evaluations. This can be a tricky task because evaluation questions need to meet certain standards and be clearly written to assess whether the center's goals are being met. Another option would be to locate some instruments through an online search engine like Google and to contact the authors for permission to use them. Lastly, some instruments for evaluation can be purchased from an established evaluation company, but this option can be expensive.

The following are examples of instruments that can be used in a QMaSC center:

1. Student Survey (Tutors) This survey can consist of several items using a five-point Likert scale: 1-Strongly Disagree, 2-Disagree, 3-Neutral, 4-Agree, 5-Strongly Agree. It can also contain a few demographic items. The purpose of this instrument would be to measure student attitudes toward tutors' ability. The topics covered can include Quality of Services, Academic Benefits, Environment, Knowledge of Content (Tutor) and Teaching Ability of Tutors. An example is provided in Appendix A.

2. Assessment Test This instrument can be developed to measure tutor proficiency in mathematics. It can test major concepts and computational skills from the main courses covered by tutors in the center. For example, tutors may be given a timed test of $15-20$ problems in which they must score at least 80 out of the maximum 100 points to be considered proficient. 
These problems can come from old final exams. An example of questions used for assessment of the tutors is provided in Appendix B. These questions were taken from an old Precalculus group final.

3. Skill Assessment Interview An instrument can be developed to measure tutor proficiency in instruction during various situations. It can be conducted as a face-to-face interview between each tutor and the internal evaluator. The interview can consist of questions regarding tutoring skills and the purpose of tutoring as well as role-play situations in which the tutor has to respond to the behavior of the internal evaluator. For example, the internal evaluator can act the role of an irate student and then ask the tutor how he or she would respond in this situation. An example is provided in Appendix C.

4. Checklist This instrument can be developed using the "Guidelines for Developing Evaluation Checklists: The Checklists Development Checklist" by Daniel Stufflebeam [5] to determine if sufficient resources, such as textbooks, worksheets, etc. are available to students who use the center.

5. Observation Instrument Random 20-minute observations can be conducted of each tutor throughout the term. An instrument can be developed to summarize these observations. The data collected can be organized in the following categories: Instructional Strategies, Organization, Communication Skills and Student/Tutor Rapport.

6. Tutor Transcripts Updated academic transcripts of tutors can also be used to determine if tutors have demonstrated proficiency in the courses in which they will tutor.

These instruments use mixed methods of data collection (qualitative and quantitative). They can be administered randomly by paper or online in the forms of open ended questions or surveys. Randomization is common for many evaluations because it can provide better material for analysis and control for bias. Also, multiple methods of analysis are helpful in supporting the validity of the evaluation being performed.

An example of an evaluation plan is presented in Table 2 on the following page. This table can be adapted for use by any mathematics or quantitative center. SPSS refers to the statistical software package offered by IBM. However, other packages and software with statistical data analysis methods can also be used.

\section{Reporting}

To create a good evaluation report, an evaluator should consider several factors. It is important to consider the audience that will receive the report because reports and presentations will need to 
Table 2: Example of an Evaluation Plan Summary for a QMaSC

\begin{tabular}{|c|c|c|c|}
\hline Evaluation Question & Source of Data & $\begin{array}{l}\text { Method of Data } \\
\text { Collection }\end{array}$ & $\begin{array}{l}\text { Method of Data } \\
\text { Analysis }\end{array}$ \\
\hline \multirow{2}{*}{$\begin{array}{l}\text { Is the QMaSC a } \\
\text { comfortable } \\
\text { learning } \\
\text { environment? }\end{array}$} & Students & Survey & $\begin{array}{l}\text { Descriptive statistics } \\
\text { and Chi-Squared } \\
\text { Test (SPSS) }\end{array}$ \\
\hline & Tutors/Students & Observation & $\begin{array}{l}\text { Observation } \\
\text { instrument data } \\
\text { summary }\end{array}$ \\
\hline \multirow{2}{*}{$\begin{array}{l}\text { How proficient are } \\
\text { tutors in calculus } \\
\text { courses and below? }\end{array}$} & Tutors & $\begin{array}{l}\text { Request Tutor } \\
\text { Transcripts }\end{array}$ & $\begin{array}{l}\text { GPA in relevant } \\
\text { math courses will be } \\
\text { computed }\end{array}$ \\
\hline & Tutors & Assessment Test & $\begin{array}{l}\text { Scored out of } 100 \\
\text { points ( } 80 \text { points }+ \\
\text { considered } \\
\text { proficient) }\end{array}$ \\
\hline \multirow{3}{*}{$\begin{array}{l}\text { How skilled are the } \\
\text { tutors at providing } \\
\text { supplemental } \\
\text { instruction? }\end{array}$} & Students & Survey & $\begin{array}{l}\text { Descriptive statistics } \\
\text { and Chi-Squared } \\
\text { Test (SPSS) }\end{array}$ \\
\hline & Tutors & Interview & $\begin{array}{l}\text { Summarize major } \\
\text { themes of interviews }\end{array}$ \\
\hline & Tutors/Students & Observation & $\begin{array}{l}\text { Observation } \\
\text { instrument data } \\
\text { summary }\end{array}$ \\
\hline $\begin{array}{l}\text { Is supplemental } \\
\text { material, such as } \\
\text { textbooks, } \\
\text { worksheets, etc., } \\
\text { available in the } \\
\text { QMaSC? }\end{array}$ & QMaSC & Checklist & $\begin{array}{l}\text { Categorical } \\
\text { (Yes/No) }\end{array}$ \\
\hline \multirow{2}{*}{$\begin{array}{l}\text { Do students feel } \\
\text { they benefit from } \\
\text { the services of the } \\
\text { QMaSC? }\end{array}$} & Students & Survey & $\begin{array}{l}\text { Descriptive statistics } \\
\text { and Chi-Squared } \\
\text { Test (SPSS) }\end{array}$ \\
\hline & QMaSC & $\begin{array}{l}\text { Sign-in } \\
\text { sheets/Attendance } \\
\text { Records }\end{array}$ & $\begin{array}{l}\text { Frequency Analysis } \\
\text { (SPSS) }\end{array}$ \\
\hline \multirow{2}{*}{$\begin{array}{l}\text { Does tutoring } \\
\text { improve student } \\
\text { understanding of } \\
\text { the material? }\end{array}$} & Students & Student survey & $\begin{array}{l}\text { Descriptive statistics } \\
\text { and Chi-Squared } \\
\text { Test (SPSS) }\end{array}$ \\
\hline & Students & $\begin{array}{l}\text { Students self-report } \\
\text { test/quiz/homework } \\
\text { scores with Access } \\
\text { ID, run of grade } \\
\text { reports for } \\
\text { mathematics courses } \\
\text { at the level of } \\
\text { first-semester } \\
\text { calculus and below }\end{array}$ & $\begin{array}{l}\text { Multiple regression } \\
\text { with final course } \\
\text { grade regressed on } \\
\text { test, quiz, homework } \\
\text { scores (SPSS) }\end{array}$ \\
\hline
\end{tabular}


be custom-designed for that particular audience. For example, the tutors do not need to receive a report on the budget of the center. This type of report would be more suitable for the business manager or dean of the center's college. Also, the report must be delivered in a timely fashion that will allow the information to be used.

Evaluation findings can be written in a report or provided during an oral presentation. Written information can be given at meetings, sent through email, listed in a blog or posted on the center's web site. With all of these methods, the internal evaluator must consider the audience and only list pertinent information. For example, budget allocation information would not be provided on a center's web site. Also, a final report should be presented to the stakeholders invested in the success of the center. "Final reports include an executive summary, an introduction, a description of the evaluation object and the questions to be answered" [1. They should also include a brief description of the evaluation plan, methodology, results and recommendations. Technical information should also be included in the appendix of the report. Oral presentations of the findings, if required, can provide a nice platform for conveying the results of the evaluation with the use of PowerPoint, handouts, and even posters.

\section{Summary}

Internal evaluation can be a useful and cost-friendly method of evaluation for a QMaSC. It can be performed by a program coordinator, director, or a group of staff members specifically assigned to the task of evaluation. The internal evaluation should be created to assess the overall quality of the program as it relates to each center's goal. This can be done through use of the CIPP Evaluation Model during the formative stage of the evaluation and during center re-evaluations. The weaknesses of this method can be minimized by the use of an additional external evaluator or by using several data collection methods for analysis. Clarity, timing and style of presentation must be considered for reporting to a specific audience. Ultimately, internal evaluation can be useful in the improvement of the center's program. It can provide data that can be used to make management decisions for improvement of the structure of the center, budget allocations, and confirmation that the center is succeeding in meeting its goals.

\section{Bibliography}

[1] J. L. Fitzpatrick, J. R. Sanders, and B. R. Worthen, Program evaluation: alternative approaches and practical guidelines. 4th edition ed., 2011.

[2] R. T. Torres, "Improving the quality of internal evaluation: the evaluator as consultant- mediator," Evaluation and Program Planning, vol. 14, pp. 189-198, 1991. 
[3] D. Stufflebeam, "CIPP evaluation model checklist." https://www.wmich.edu/sites/default/ files/attachments/u350/2014/cippchecklist_mar07.pdf, 2015.

[4] D. Stufflebeam, "Evaluation values and criteria checklist." https://www.wmich.edu/sites/ default/files/attachments/u350/2014/values_criteria.pdf, 2015.

[5] D. Stufflebeam, "Guidelines for developing evaluation checklists: the checklists development checklist." https://www.wmich.edu/sites/default/files/attachments/u350/2014/ guidelines_cdc.pdf, 2013. 


\section{Appendix A}

\section{QMaSC Student Satisfaction Survey - A few sample statements}

Directions: Please circle the number that best fits your response where

$1=$ Strongly Disagree, $2=$ Disagree, $3=$ Neutral, $4=$ Agree, $5=$ Strongly Agree

1. The Center provided the services that I needed.

$\begin{array}{lllll}1 & 2 & 3 & 4 & 5\end{array}$

2. The quality of tutoring meets my needs.

$\begin{array}{lllll}1 & 2 & 3 & 4 & 5\end{array}$

3. The staff makes me feel comfortable.

$\begin{array}{lllll}1 & 2 & 3 & 4 & 5\end{array}$

4. The Center has suitable hours of availability.

$\begin{array}{lllll}1 & 2 & 3 & 4 & 5\end{array}$

5. The tutors are knowledgeable and help in the understanding of my coursework.

$\begin{array}{lllll}1 & 2 & 3 & 4 & 5\end{array}$

6. I would recommend the Center to others.

$\begin{array}{lllll}1 & 2 & 3 & 4 & 5\end{array}$

7. Overall, the Center is a good source for mathematics help.

$\begin{array}{lllll}1 & 2 & 3 & 4 & 5\end{array}$

Please provide any additional questions or comments regarding the Mathematics Resource Center on the lines below. 


\section{Appendix B}

\section{QMaSC Tutor Assessment for Precalculus}

Read the directions to each problem carefully. ALL WORK MUST BE SHOWN. Each problem is worth 5 points. DO NOT USE A CALCULATOR.

1. Find the domain of the function $f(x)=\frac{e^{x}+\ln \left(1-\frac{3}{2}\right)}{\sqrt{4 x+1}}$.

2. Find the average rate of change of the function $f(x)=-x^{2}+2 x-3$ from $x=-2$ to $x=5$.

3. Let $f(x)=2-\frac{3 x}{3 x-1}$. Find $f^{-1}(x)$, where $f^{-1}$ is the inverse function of $f$.

4. Let $f(x)=\frac{1-x}{1+x}$ and $g(x)=1-\frac{2 x}{x+1}$. Find the function $(f \circ g)(x)$ and simplify your answer.

5. Graph the polynomial $p(x)=-x^{2}(x+2)^{3}$, finding and labeling all intercepts.

6. Graph the function $f(x)= \begin{cases}(x+1)^{2}, & x<0 \\ 2-x, & 0 \leq x \leq 2 \\ 5, & x>2\end{cases}$

7. Find all the zeros of the polynomial $p(x)=2 x^{3}+10 x^{2}+9 x+4$. Please express any non-real zeros in the form $a+b i$.

8. Graph the function $g(x)=\frac{x^{2}+x-6}{x^{2}-25}$, labelling all intercepts and asymptotes.

9. Solve the equation $2 e^{x}-1=3 e^{-x}$.

10. The general function $n(t)=n_{0} e^{k t}$ is used to model the number of bacteria in a certain culture, where the time $t$ is measured in hours. Suppose the culture initially contains 630 bacteria. After 3 hours the bacteria count is 1050 . find the exact time it took for the bacteria count to grow to four times its initial size. Simplify your answer.

11. Find all the values of $x$, if any, such that $\log _{4}(x+6)-2=\log _{4}(5-x)$.

12. Simplify the expression $\ln \left(e^{3 \ln \left(e^{2}\right)}\right)+4^{-2 \log _{4}(1 / 2)}$.

13. Find the exact value of each trigonometric function at the given real number, if it exists.
a. $\csc (-5 \pi / 3)$
b. $\cos (15 \pi / 4)$.

14. Find and state the amplitude and period length of the function $f(x)=4 \sin \left(\frac{1}{3} x-\frac{\pi}{12}\right)-1$ and graph one complete period. Be sure to label the highest and lowest points on the graph.

15. Given that $-\pi / 2 \leq \theta \leq \pi / 2$ and $\csc \theta=-5 / 2$, find the value of $\cos (\pi / 6-\theta)$.

16. Find the exact value of each expression, if it exists.
a. $\sin \left(\sin ^{-1}(\pi-3)\right)$
b. $\cos ^{-1}(\cos (11 \pi / 6))$.

17. Find the exact value of $\cot \left(\sin ^{-1}(12 / 17)\right)$. 
18. Verify that the trigonometric equation is an identity.

$$
\frac{\cot x-\tan x}{\sin x \cos x}=\csc ^{2} x-\sec ^{2} x
$$

19. Find all primary solutions (i.e. $0^{\circ} \leq x<360^{\circ}$ ) to the equation $\frac{1}{2}(\sin 2 x)(\cos 2 x)=\sin x \cos x$.

20. Two strings stretch from a balloon to two posts on the ground which are 100 feet apart. String 1 is attached to a post that lies to the left of the balloon and string 2 is attached to a post that lies to the right of the balloon. String 1 forms a $57^{\circ}$ angle with the ground and string 2 forms a $79^{\circ}$ angle with the ground. How high up is the balloon? Simplify your answer. 


\section{Appendix C}

\section{QMaSC Tutor Interview - Sample guided questions and role play situations}

Open Ended Questions:

1. What do you feel your purpose is as a tutor?

2. How confident are you in your ability as a tutor?

3. What do you do when you are presented with a problem that you cannot solve/explain?

4. How does tutoring affect your current situation? Classes? Time?

5. Are there any issues that you are concerned with as a student/tutor?

6. Overall, how would you rate yourself as a tutor and why?

7. Do you have any recommendations for the center?

\section{Role Play Situations:}

1. Evaluator pretends to be an irate student that yells and complains about his/her math course in hopes of observing the tutor's honest reaction in dealing with the attitudes and behaviors of a student frustrated in mathematics.

2. Evaluator pretends to be a thoroughly confused student on a specific mathematics problem in hopes of observing the tutor's ability to dissect the situation and offer alternative examples and explanations of the material. 